\title{
The Beginning of Marine Sustainability: Preliminary Results of Measuring Students' Marine Knowledge and Ocean Literacy
}

\author{
Yen-Ling Lin ${ }^{1}{ }^{(\mathbb{C}, \text { Liang-Yu Wu }}{ }^{2}$, Liang-Ting Tsai ${ }^{3, *}$ and Cheng-Chieh Chang ${ }^{4, *(\mathbb{D})}$ \\ 1 Taiwan Marine Education Center, National Taiwan Ocean University, Keelung 20224, Taiwan; \\ linyenling0619@gmail.com \\ 2 Masai Elementary School, Yilan 27050, Taiwan; ewlyu@mail2000.com.tw \\ 3 Institute of Education, Tzu Chi University, Hualien 97004, Taiwan \\ 4 Institute of Education \& Center of Teacher Education, National Taiwan Ocean University, \\ Keelung 20224, Taiwan \\ * Correspondence: tsai5128@mail.tcu.edu.tw (L.-T.T.); changjac@email.ntou.edu.tw (C.-C.C.); \\ Tel.: +886-3-8565301-2940 (L.-T.T.); +886-2-24622192-1242 (C.-C.C.)
}

Received: 20 July 2020; Accepted: 27 August 2020; Published: 31 August 2020

check for updates

\begin{abstract}
Ocean sustainability and resource use are emphasized globally. The primary goal of ocean preservation is to enhance citizens' ocean literacy. In this study, cluster sampling was conducted on students from seven public middle schools in Taiwan to investigate their use of ocean literacy concept words, propositional sentences, and knowledge sources. Qualitative analysis, descriptive statistics, and one-way analysis of variance were conducted on 496 valid questionnaires. The middle school students exhibited an accuracy rate of $63 \%$ for ocean literacy sentence-making, which indicated a basic level of performance. The students commonly used terms such as "ocean," "Atlantic Ocean," and "tsunami." Students had common misconceptions when using the terms "sea level rising," "Kuroshio current," and "tsunami." In addition, students who were female, in a higher grade, and who attended a coastal school had higher ocean literacy scores. The students' primary sources of ocean literacy knowledge were museums and television. Through an analysis students' use of ocean concept words and misconceptions, the aim of this study was to enhance the implementation efficiency of marine education to cultivate students' ocean literacy.
\end{abstract}

Keywords: marine education; ocean literacy; sustainable development goals; misconception; marine sustainability

\section{Introduction}

Since the Industrial Revolution, the consumption rate of natural resources by humans has rapidly increased, resulting in environmental pollution, declining ecosystem quality, and various social problems. Against this backdrop, the need for environmental education and education for sustainable development has emerged. Through the integration of human resources and other resources at different times as well as both formal and nonformal education systems, people's comprehensive ability to construct a sustainable society can be cultivated. Historically, the nature of environmental education is its focus on the terrestrial environment; however, to address the dual goals of sustainability and education, environmental education should focus on both land and sea education. In 1988, the United Nations (UN) proposed the Education for Sustainability approach, which concerned the objectives, nature, mission, and content of environmental education. In 1992, the concept of sustainable development was transformed into a concrete action plan, and education was stated to be a key factor in advancing the goal of sustainable development. From the perspective of environmental protection, 
sustainable development is promoted and people's ability to solve environmental and developmental problems is enhanced through education. Education is also the key to maintaining the progress and development of human society. Since 2000, the UN has proposed the Millennium Development Goals and Education for Sustainable Development program [1,2]. In 2015, the UN announced the Sustainable Development Goals, which comprise 17 core goals for governments and corporations worldwide to achieve sustainable development. The 14th goal states the following: "Conserve and sustainably use the oceans, seas and marine resources for sustainable development." Therefore, teaching citizens about current marine affairs, ensuring the basic ocean literacy of the next generation, accepting the importance of the ocean, and enhancing the competitiveness of domestic industries are fundamental to environmental education.

In 1982, the UN established its Convention on the Law of the Sea, which regulates the maritime activities of oceanic countries and their maritime rights and provides comprehensive regulations on policy formation, law enactment, and organization establishment [3]. Following the establishment of the Convention, several countries established maritime policies and regulations and strived to enhance their citizens' understanding of the ocean, which indicates that most countries value the critical problems pertaining to resource development and environment change. Since 2000, countries have been investigating their citizens' ocean literacy. To promote the understanding of the importance and value of protecting the ocean, numerous countries have stressed problems pertaining to ocean environments and marine education as well as defined the understanding of these problems as "ocean literacy." Thus, a person with ocean literacy has the ability to understand the basic principles, fundamentals, and concepts of the ocean; to communicate about the ocean meaningfully; and to make informed and responsible decisions about ocean resources. To this end, ocean literacy can be viewed as a means of incorporating scientific literacy into education; with this, the ability to make socially responsible decisions is acquired. Therefore, cross-region and cross-nation professional communities have distributed various survey instruments to investigate ocean literacy, such as the United States' International Ocean Literacy Survey and Greece's Survey of Ocean Literacy and Experience. These surveys have assessed the understanding of ocean literacy principles and the development of relevant concepts among students of various grades, thereby emphasizing that all citizens should understand the importance of the ocean and the necessity of protecting its environments $[4,5]$.

The meaning of marine education in Taiwan has evolved from the conventional objective of cultivating marine professionals to the current goal of teaching general education courses containing ocean literacy [6]. In 2001, the government issued the White Paper on Marine Policy, which declared Taiwan as a "marine country" and promoted marine research and humanistic education. Subsequently, the White Paper on Marine Education Policy released in 2007 implemented the concept of a "marine country" and comprehensively promoted marine development, marine professional cultivation, and marine education enhancement for citizens. Regarding educational policies, marine education topics were implemented in the Grade 1-9 Curriculum Guidelines proposed in 2008. In the Curriculum Guidelines of the 12-Year Basic Education program established in 2019, marine education topics and the importance of each subject were integrated to enable students to learn about the five main learning themes of marine education (i.e., marine leisure, marine society, marine culture, marine science and technology, and marine resources and sustainability), thereby shaping an educational environment that advocates awareness of, love for, and closeness with the ocean. Thus, the government aims to ensure citizens have ocean literacy and promote Taiwan's synergy in sustainable development as a maritime country [7-11].

After ocean literacy curriculum guidelines and textbooks were introduced to address the interdisciplinary learning characteristics of marine education topics, capability indicators and substantive connotations were integrated into marine education. However, such integration requires teachers to be familiar with the teaching content to ensure teaching performance is not hindered, schools' promotion of ocean literacy is not impeded, and learning outcomes do not stagnate [12,13]. Studies have indicated that during teacher training and in each teaching grade, educational institutions 
generally provide sparse marine education resources for teachers. Furthermore, the degree of marine education integrated in textbooks is unsatisfactory. In senior and vocational high schools that are not marine-related, marine education content accounts for $2-5 \%$ of teaching materials. In middle and elementary schools, the proportion is lower than 5\%; specifically, these schools' marine educational content focuses on the beauty of marine environments and the joy of playing at the beach. In middle schools, marine educational content introduces marine life, waves, currents, and pollution [13-15]. In summary, a shortage of marine educational resources and limitations on teaching time mean that schools include little content knowledge on ocean literacy. To enable citizens to thoroughly understand the ocean and effectively use ocean resources, developing students' ocean literacy through formal education, enhancing their overall respect for and protection of the natural environment, and enabling them to perceive that marine and land development are equally crucial problems that warrant discussion.

In response to current changes in society and the arrival of globalization, schools must implement the teaching of ocean-related topics to complement and enhance students' understanding. In studies on the ocean science literacy of senior and vocational high school students, participants only answered $50 \%$ of the questions correctly, indicating that much room for improvement remains [16,17]. In recent years, Taiwanese scholars have established connections and formed partnerships with international marine educational communities and employed Chinese versions of surveys to investigate the influence of background variables on students' ocean literacy. These surveys have assessed students' understanding of ocean knowledge and encouraged a positive attitude toward acquiring ocean literacy for use in solving life problems [18-20]. Currently, marine education has been promoted for much more than 10 years in Taiwan. The aforementioned research results serve as a policy promotion strategy for marine education and ocean literacy in senior and vocational high schools. However, no empirical studies have been conducted on the expected degree of middle school students' understanding and capabilities pertaining to ocean knowledge and concepts.

Teachers are pivotal in successfully promoting marine education. In particular, how teachers convert marine education curricula into teaching implementation strategies is a determining factor in how effectively marine education can be implemented. In the past, Taiwan's teacher training process did not provide marine education-related courses. This caused teachers to generally have poor ocean knowledge and concepts and insufficient teaching knowledge for marine education. Schools lacked clear regulations for marine education, resulting in limitations in teachers' willingness, teaching content, and teaching methods. In addition, domestic studies have revealed that most teachers acknowledge not having graduated from ocean-related programs. Because of a lack of professional marine knowledge and backgrounds, teachers would have had to self-research extracurricular information on ocean knowledge and extend their original teaching designs. Furthermore, teachers were concerned that their poor understanding of and resources for ocean knowledge could result in misconceptions in students. Moreover, teachers were subjected to work adjustments and psychological stresses from their insufficient basic marine knowledge [12,21].

This study investigated middle school students' prior knowledge and concepts on ocean literacy and employed concept map sentences to assess and diagnose students' misconceptions. This study provided school teachers with practical strategies and support for course development and teaching and teaching resources. Thus, it serves as a reference for school teachers and relevant units concerned with the development of marine education in their course development and teaching designs. To understand the influence of backgrounds on students' ocean literacy and enhance the learning outcomes of marine education, this study employed propositional concept map sentences to assess students' marine concepts and determine their misconceptions. This study represents an attempt to achieve the following objectives using propositional concept maps:

1. To investigate middle school students' marine concepts.

2. To assess marine concepts and the literacy of middle school students with different backgrounds.

3. To diagnose middle school students' ocean literary and misconceptions. 


\subsection{Importance of Ocean Literacy}

In 1989, UNESCO compiled expert suggestions from the marine science field, science education field, government agencies, educational units, and community education centers. After investigating marine science education, teacher training, and academic research, the organization proposed a direction for marine education. The organization stated that marine science education should develop toward interdisciplinary science, practicality, and professionalism. Subsequently, the organization categorized marine education into professional marine science education-which focuses on marine professional courses, stresses the importance of developing marine professional knowledge, and cultivates marine professionals-and general marine science education, which concerns the general public's understanding of marine science education and literacy and aims to improve citizens' awareness and understanding of marine environments, information management, and ecological preservation [22].

In 1996, the United States published an investigation on the National Science Education Standards and revealed that the course standards and content in each state did not include teaching material content on the ocean, coastal areas, or ocean areas. In addition, reports have indicated that US students and citizens have little knowledge of the ocean, oceanic concepts, aquatic species, and humanistic and cultural subjects. In addition, US citizens have little knowledge of the interactive mechanisms between the climate and the ocean [23-26]. In 2002, the US National Marine Educators Association proposed national ocean science education standards with ocean literary as the main theme and established 7 principles and 45 basic concepts. Ocean literary answers the question: "How does the ocean influence you, and how do you influence the ocean?" This emphasizes that citizens are expected to understand the mutual influence between the ocean and humans [27]. The aforementioned seven principles are as follows: (1) The Earth has one big ocean with many features; (2) the ocean and life in the ocean shape the features of the Earth; (3) the ocean is a major influence on weather and climate; (4) the ocean makes the Earth habitable; (5) the ocean supports great diversity of life and ecosystems; (6) the ocean and humans are inextricably linked; and (7) the ocean is largely unexplored. These principles emphasize the importance and diverse characteristics of the ocean [28]. Principle 3 corresponds to social equity, principle 4 corresponds to environmental integrity, principle 6 corresponds to sustainability, and principle 7 corresponds to economic prosperity, when compared with sustainable education that emphasizes environmental, social, and economic value [29-31].

By adhering to these principles, the US government and citizens actively engage in marine-related courses by providing open-ended learning through elementary school to high school and implementing multimedia interactive courses and concept map design courses to support students in learning marine concepts. These principles also grant junior college students and citizens access to informal learning methods (e.g., short-term experiences, experimental projects, and community education centers), which enable holistic lifelong learning to effectively enhance citizens' ocean literacy [28].

Marine education is interdisciplinary and features talent cultivation systems at different educational stages. Despite differences between Taiwan's marine education problems and the United States' ocean literacy-based marine science knowledge, interdisciplinary knowledge remains the essence of marine concepts. It supports educators in integrating marine concepts and knowledge in the classroom and outdoors to enable students to learn through experiencing natural environments and ocean areas, thereby enhancing their ocean literacy [32,33]. Therefore, Taiwan's focus on ocean literacy involves ocean-oriented education, which includes learning about the ocean and ocean concepts (cognitive aspect), the use and preservation of ocean environments (technological aspect), and the cultivation of care and appreciation toward the ocean (emotional aspect). Ocean education allows learners to understand their environment, develop positive values, understand how to interact with the ocean, and understand the importance of ocean-related sustainable development.

This information and research revealed the urgent need to improve teachers' ability to collect, compile, assess, and evaluate marine teaching resources. For teachers to successfully integrate these resources into teaching, their teaching resources and strategies as well as their ability to assess students' basic abilities are pivotal. Therefore, understanding middle school students' comprehension of marine 
concepts and being able to diagnose students' misconceptions are valuable references for teachers of all grades to design marine-related courses.

\subsection{Theory and Evaluation of Concept Maps}

Learning involves conceptual change and exploration. Human learning is conducted from cognition. Regarding meaningful learning, US cognitive psychologist David Ausubel posited that new knowledge must be connected to a learner's prior knowledge and experience to form a greater and broader conceptual framework and become the learner's prior knowledge for future learning [34,35]. Professor Novak from Cornell University, United States, employed the meaningful learning theory of Ausubel and proposed concept mapping as a learning tool to help students learn how to learn [36]. This tool is used to integrate and hierarchically sort concepts to present their relationships. Through the adoption of propositional descriptions, concept mapping employs a two-dimensional shape to depict and represent the conceptual framework. Subsequently, concept mapping expands each "node" of learning into "areas" of learning and includes all learning concepts in propositions. Through integrating and establishing a hierarchy, concept mapping presents the relationships between concepts, indicates the qualities that are beneficial to learners, and constructs and reconstructs knowledge structures. Concept maps employ a series of propositions to establish meaningful connections between known and new concepts to create an organizational network. Through the map, learners' knowledge structures and misconceptions can be identified to serve as a reference for assessing their conceptual frameworks [36,37].

Piaget stated that learners' incorrect schema or prior knowledge are incorrect concepts or misconceptions. In general, this refers to learners' direct viewpoints toward natural phenomena, social events, witnessed events, and the surrounding environment at the start of learning. Before these viewpoints are subjected to challenges, most of the concepts originate from learners' personal experience, family education, peer influence, read literature, and sociocultural influences [38]. However, these viewpoints are often commonly proven incorrect by scientific theories. For example, some elementary students believe misconceptions such as that "candlelight spreads further during the night" and "gravity does not exist in a vacuum" [39]. Therefore, assessing students' misconceptions is a difficult yet crucial task for teachers. Concept maps are effective teaching tools that can support students by clarifying the relationships between concepts and highlight differences in students' knowledge [40]. Therefore, by using concept maps to collect students' learning history, knowledge, and understanding of a topic, teachers can use the portrayed concept relationships and hierarchical arrangements to diagnose their knowledge structure and misconceptions. This will enable teachers to establish learning motives and encourage students to actively learn correct and meaningful concepts.

Learning is a type of exploration in which individuals' cognitive structure is constantly assimilated, adjusted, integrated, and changed to include new concepts, which ultimately changes individuals' original concepts [41]. During the conceptual change process, students can create concept maps to reconsider and create self-adjustments to their conceptual framework. Early studies on the conceptual framework of science education have revealed the following five types of conceptual change: (1) concept acquisition, in which a learner assimilates new concepts into the preexisting conceptual framework and changes its "quality"; (2) concept restructuring, in which cognitive conflicts are encountered and the learner restructures or differentiates preexisting concepts to accept new knowledge concepts, thereby changing their "quantity"; (3) concept replacement, in which the learner replaces preexisting concepts with new concepts; (4) concept coexistence, in which new and old concepts are included in the learner's conceptual framework; and (5) concept enhancement, in which the learner's concepts are enhanced by assimilating and adjusting new and old concepts [42,43].

Therefore, students can use concept maps to review their conceptual framework, revise, restructure, assimilate, and adapt to effectively enhance their ability to categorize knowledge, and integrate new knowledge to achieve meaningful learning. In addition, teachers can determine whether students' concepts are correctly connected and whether their knowledge hierarchy is correctly arranged to 
understand their learning conditions and detect their knowledge structures and misconceptions. Therefore, concept maps are effective assessment tools for both teachers and students.

\subsection{Ocean Literacy Studies}

Japan implemented teaching guidance policies across different stages of education and research and also developed additional teaching materials to strengthen students' ocean literacy, to encourage citizens to love and protect the ocean, elicit human-ocean interactions, and use ocean resources [44]. Taiwan adopted the holistic educational spirit of the 12-year Basic Education program as a starting point and employed core literacy as the course development principle to nominate marine education as an educational topic, which indicates that ocean literacy encompasses science and social aspects. However, few studies have discussed these topics [45,46]. From a scientific aspect, official education systems and place-based courses on geology, chemistry, and biology have included the discussion and development of teaching strategies for ocean literacy [47-49]. In Italy, Croatia, and Greece, where 65\% of the population live by the Mediterranean Sea, children in grades 3-6 have an intermediate level of knowledge of marine science and most often acquire it through knowledge of the oceans in coastal areas, environmental activities in schools, and television documentaries [50].

A research survey from the American Association for the Advancement of Science on oceanic and environmental literacy for adults indicated that citizens have a positive attitude toward the ocean. However, they insufficiently understand ocean-related knowledge and concepts and influences on the ecosystem environment, and they also lack awareness of basic environmental ocean literacy. Because of the mutually dependent relationship, the ocean literacy demand of citizens who live near coastal regions should be prioritized [51]. In addition, an investigation on the ocean literacy and motivation of young adults indicated strong ocean awareness, environmental attitudes and morals regarding the ocean, and an understanding of ocean-related social problems among young adults. The results indicated that young adults' understanding of ocean knowledge is significantly influenced by their environmental attitudes. Individuals who have personal experiences with the ocean have a greater degree of ocean knowledge [52]. In addition, college students generally hold misconceptions regarding marine meteorology, marine chemistry, and marine biology and pollution, which indicate their lack of ocean literacy [53]. Furthermore, the general public does not sufficiently interact with the ocean. Their interaction is generally limited to the tides and waves, and they have an unorganized knowledge structure [54].

Humans have strived to explore and understand the ocean. Scholars across scientific fields have suggested that misconceptions occur in the learning [55,56]. Literature and empirical studies have revealed that concept maps are viable tools for teaching information and concepts. In addition, they can be used to diagnose and assess insufficiencies and misconceptions in students' prior knowledge. Currently, various aspects of the ocean remain unknown and require exploration. Although students may be familiar with the ocean, misconceptions and incomplete knowledge structures commonly persist in their professional understanding of the ocean. This empirical study employed propositional concept maps to implement and establish fundamental and correct marine concepts, teach applicable knowledge and techniques, and correct misconceptions to cultivate a teaching spirit consisting of ocean literacy.

\section{Materials and Methods}

\subsection{General Background of the Research}

This study constructed a research tool through studying the literature and conducting expert interviews. Questionnaire surveys were distributed to collect information. First, 100 basic conceptual terms related to the ocean were collected and compiled from the literature. Subsequently, seven experts, including a college professor, a researcher, and five teachers of natural science fields in middle schools with expertise in marine education were interviewed. We employed assessment items to 
investigate the marine concepts and misconceptions of middle school students. To assess students' ocean literary, the items included students' demographic information, a concept mapping assessment that entailed making sentences using 50 ocean-related concept words, and students' main sources of ocean knowledge and concepts.

\subsection{Research Sample}

For this research, cluster sampling of public middle schools was conducted and one class was selected from the seventh, eighth, and ninth grades of each school for investigation. A total of 500 questionnaires were distributed and retrieved, of which four were invalid and excluded, resulting in 496 valid questionnaires and a valid response rate of $99.2 \%$. Middle school students learned ocean literacy by studying several ocean science courses. In addition, the students learned excerpts of ocean literacy in the field and through courses integrated with marine educational topics.

\subsection{Instrument and Procedures}

\subsubsection{Construction Process and Application of 50 Terms Related to Ocean Concepts}

A literature review was conducted to collect 100 basic nouns and terms related to key concepts regarding the ocean (hereinafter "ocean-related concept words"), including basic ocean concepts, seawater properties, ocean ecosystems, marine technology, and ocean organisms [16,17]. Subsequently, seven academics were invited to select 30 concept words from the collected 100 words according to the curriculum content used in middle school and student capabilities. These experts selected marine vocabulary based on the curriculum of the Ministry of Education in the field of natural science and the topics and contents of marine concepts in junior high school education mentioned in the textbooks. Then, 157 of the students who participated in a preliminary test were invited to select 20 concept words they had learned or that they understood from the 100 ocean-related concept words.

\subsubsection{Propositional Concept Map Assessment Using Ocean-Related Concept Words}

There are three assessment modes for concept maps: node-linking scoring [36], expert-novice difference percentage scoring [57], and propositional scoring. This study employed propositional scoring, an open-ended scoring method that allows students to complete assignments by holding interviews or completing homework under limited conditions. Subsequently, teachers and researchers revised and scored the concept maps according to the accuracy, explanation, and proposition structure. The dimensions were scored flexibly. The scoring weights were determined by scorers [58]. This study employed the 50 ocean-related concept words to create the questionnaire content. Students were requested to make 10 sentences based on ocean literacy concepts that they knew. Each sentence had to contain at least two ocean-related concept words. After the student questionnaires were retrieved, the open-ended propositions were scored according to their accuracy, explanation, and proposition structure. Propositions could attain 5, 3, 1, and 0 points in each dimension. For the accuracy dimension, the propositions were classified and scored according to scientifically accurate, commonly known, affective, and inaccurate knowledge. The explanation dimension classified and scored propositions into higher-order explanations and descriptions. The proposition structure was classified into compound and simple categories [58]. Table 1 provides detailed examples and is a reference for the scoring method. From the retrieved questionnaires, the 10 propositional concept map sentences written by the students were statistically recorded and compiled to reveal the mean and standard deviation of the data. Then, the students' misconceptions were analyzed, and an ocean concept list was compiled according to the assessment results. This list enabled an understanding of the middle school students' awareness of ocean literacy and related concepts and can serve as a reference for teaching. Subsequently, another teacher scored the students' ocean literacy misconceptions based on their open-ended propositions. The inter-rater reliability of the accuracy, explanation, and proposition structure dimensions were 0.91 , 0.86 , and 0.85 , respectively. 
Table 1. Scoring system of the propositional concept map sentences with ocean-related concept terms.

\begin{tabular}{cclc}
\hline Dimension & \multicolumn{1}{c}{ Category } & \multicolumn{1}{c}{ Example } & Score \\
\hline \multirow{2}{*}{ Accuracy } & Scientifically accurate & Earthquakes cause tsunamis. & 5 \\
& Commonly known & Sharks live in the ocean. & 3 \\
& Inaccurate knowledge & Alligators are mammals. \\
& Affective & Tropical fish are beautiful. & 0 \\
& Descriptions & $\begin{array}{l}\text { Anglerfish have a luminescent organ } \\
\text { that is similar to an earring. }\end{array}$ & 3 \\
Explanation & Higher-order & $\begin{array}{l}\text { Anglerfish have a luminescent organ } \\
\text { that is similar to an earring above their }\end{array}$ & 5 \\
& explanations & mouths, which attracts prey. & 3 \\
\multirow{2}{*}{ Proposition structure } & Simple & Organisms live in the ocean. & 5 \\
\hline & Compound & Corals are ocean animals. & $0-15$ \\
\hline
\end{tabular}

Propositions that answer "how" or "why" causal relationships are classified as higher-order explanations in the explanation dimension.

\subsubsection{Sources of Marine Concepts}

The third part of the questionnaire investigated students' main sources of marine concepts. Students were required to select their learning channels, including instruction by school teachers, school promotion (e.g., expert lectures, beach cleanups, and garbage sorting), self-learning, visits to marine museums, news media broadcasts, viewing of ocean-related videos (e.g., BBC, Discovery Channel, and Animal Planet), watching cartoons about the ocean, reading books on the ocean, and getting information from friends or family members (e.g., senior family members). Furthermore, students could select multiple answers to describe their sources and channels of ocean concepts. In the future, these channels can be employed to reinforce students' ocean concepts and literacy.

\subsection{Data Analysis}

This study employed descriptive statistics to present the acquired statistics and percentages of each background variable of the sample. Subsequently, $t$-test analysis was performed to determine whether the ocean literacy of middle school students with different background variables exhibited significant differences $(\alpha=0.05)$. In addition, a one-way analysis of variance was used to determine whether the accuracy, explanations, and proposition structures were significantly different. Subsequently, the Scheffe test was employed for a post hoc analysis of propositions exhibiting significant differences among the three dimensions. To understand the ocean literacy of middle school students, we conducted a qualitative analysis of the student propositions from ocean-related term words. From the four dimensions (i.e., competency, knowledge, attitude, and scenario) of the theoretical framework of The Programme for International Student Assessment by the Organization for Economic Co-operation and Development and the three dimensions (i.e., cognitive, affective, and sensory) of Bloom's educational objectives, the researchers adopted knowledge, attitude, and affective dimensions to analyze the students' expressed content [59]. The categorization standards were based on whether the text description was correct and consisted of factual content (knowledge), disseminated concepts or connotations to protect ocean environments (attitude), and expressed affective factors (affective). Propositions may have fulfilled two or three of these categorization standards simultaneously. If the expressed proposition contained an incorrect connotation, the proposition was considered a misconception. 


\section{Results}

\subsection{Analysis of Middle School Students' Ocean Concepts from Propositional Concept Map Sentences}

Propositions based on the 50 ocean-related concept words were evaluated through assessing the 10 sentence-making items (i.e., students made sentences using the 50 concept terms). The propositions were scored and analyzed from the three dimensions of open-ended items: their accuracy, their explanation, and their structure. Subsequently, the scores of the 10 items were totaled, and the lowest and highest possible scores of each dimension were 0 and 50, respectively. Then, $10 \%$ of the students were selected for concept assessment analysis. After an assessment by two teachers, the inter-rater reliability of the accuracy, explanation, and structure of the propositions was $0.80,0.85$, and 0.70 , respectively. Table 2 indicates that the total mean accuracy score of the students' ocean concept propositions was 33.28, which suggested that the degree of accuracy among students' concept term usage was $66 \%$. This represented students' factual knowledge. The total mean explanation score was 30.86 , which implied that the students exhibited a $60 \%$ correct rate when answering items in the explanation dimension. This indicated that most students formed descriptive sentences, and a few formed higher-order explanation sentences containing causal relationships. Finally, the students had a total mean proposition structure score of 31.60 points, which indicated that their rate of constructing sentences correctly in the propositional dimension was $62 \%$. This indicated that students were prone to writing simple sentences. These results revealed that the students understood only basic ocean literacy concepts in the propositional concept map sentences. Therefore, the cultivation of ocean literacy in middle school is insufficient, and students' ocean knowledge should be improved.

Table 2. Analysis of the propositional concept map sentences according to the dimensions.

\begin{tabular}{|c|c|c|c|c|c|c|c|c|c|}
\hline & \multirow{3}{*}{ Variable } & \multicolumn{8}{|c|}{ Constructs } \\
\hline & & \multicolumn{2}{|c|}{ Accuracy } & \multicolumn{2}{|c|}{ Explanation } & \multicolumn{2}{|c|}{$\begin{array}{l}\text { Proposition } \\
\text { Structure }\end{array}$} & \multicolumn{2}{|c|}{ Total } \\
\hline & & $\mathbf{M}$ & SD & $\mathbf{M}$ & SD & $\mathbf{M}$ & SD & $\mathbf{M}$ & SD \\
\hline \multirow{2}{*}{ Gender } & Males & 32.67 & 12.40 & 25.53 & 8.91 & 25.53 & 14.50 & 83.73 & 35.81 \\
\hline & Females & 34.50 & 12.24 & 26.18 & 8.50 & 26.18 & 14.00 & 86.86 & 37.74 \\
\hline \multirow{2}{*}{$\begin{array}{l}\text { School } \\
\text { location }\end{array}$} & Coastal school & 35.67 & 9.63 & 27.40 & 6.33 & 42.76 & 10.43 & 105.83 & 26.39 \\
\hline & Inland school & 28.12 & 16.39 & 21.86 & 12.16 & 33.18 & 19.67 & 83.16 & 48.22 \\
\hline \multirow{3}{*}{$\begin{array}{l}\text { Students' } \\
\text { family }\end{array}$} & Marine industries & 34.11 & 12.36 & 26.68 & 8.68 & 41.06 & 13.99 & 101.85 & 35.02 \\
\hline & Non-marine-related industries & 33.50 & 12.35 & 25.73 & 8.71 & 39.96 & 14.30 & 99.19 & 35.36 \\
\hline & Total & 33.28 & 12.44 & 30.86 & 8.78 & 31.60 & 14.33 & 95.74 & 35.55 \\
\hline
\end{tabular}

\subsection{Usages and Misconceptions of Middle School Students Using Ocean-Related Concept Words}

The students' usage of the 50 ocean-related concept words in their answers was influenced by their understanding. The three most commonly used terms by the students were "ocean," "Atlantic Ocean," and "tsunami." In addition, the students had several incorrect usages and misconceptions when making sentences using the 50 terms. Based on their usages, the students' most common misconceptions of the ocean concerned the terms "sea level rising," "Kuroshio current," and "tsunamis." By compiling students' ocean literacy propositions according to the knowledge, attitude, and affective dimensions, the concept terms used in the propositions were found to be mainly common ocean-related topics and nouns, such as "earthquake," "warming," "polar bears," "sea turtles," and "jellyfish." Furthermore, the propositions were mainly simple and homogeneous, and few of the propositions comprised comprehensive and complex concepts (Table 3). In addition, propositional concept map sentences of the middle school students revealed specific sentence-making patterns that were more likely to result in incorrect concepts and misconceptions. Table 4 explains the correct examples. 
Table 3. Categories and examples of middle school students' propositional concept map sentences.

\begin{tabular}{|c|c|c|}
\hline Category & Example & Coding \\
\hline \multirow{6}{*}{ Knowledge } & \multirow{6}{*}{$\begin{array}{l}\text { There are many seashells on the beach. } \\
\text { Fish schools play freely in the ocean. } \\
\text { The ocean constitutes approximately } 70 \% \text { of the } \\
\text { Earth's surface. } \\
\text { Typhoons are part of the water cycle. } \\
\text { Temperatures change during different parts of the } \\
\text { water cycle. }\end{array}$} & A9021 \\
\hline & & H7004 \\
\hline & & G7015 \\
\hline & & \\
\hline & & E8008 \\
\hline & & F9006 \\
\hline \multirow{3}{*}{ Attitude } & \multirow{3}{*}{$\begin{array}{c}\text { The pressure is greater in deeper parts of the ocean. } \\
\text { Polar bears and penguins live in arctic climates. } \\
\text { Due to poor environmental protection, trash is always } \\
\text { floating in the ocean. }\end{array}$} & E8026 \\
\hline & & F9002 \\
\hline & & G7022 \\
\hline \multirow{3}{*}{ Affection } & $\begin{array}{l}\text { Many people like to snorkel at the beach to enjoy the beauty } \\
\text { of the ocean. }\end{array}$ & E8008 \\
\hline & Many cute penguins live in Antarctica. & H7001 \\
\hline & Many cute clownfish live in coral reefs. & G9012 \\
\hline \multirow{4}{*}{ Knowledge + Attitude } & $\begin{array}{l}\text { Scientists have discovered unique marine organisms at the } \\
\text { bottom of the ocean. }\end{array}$ & A9016 \\
\hline & Sea turtles eat jellyfish to prevent their overpopulation. & B8003 \\
\hline & $\begin{array}{c}\text { Little sunlight penetrates the ocean depths. Therefore, } \\
\text { marine organisms that live in deeper parts of the ocean } \\
\text { are unique. }\end{array}$ & H9018 \\
\hline & $\begin{array}{l}\text { Underwater volcano eruptions may cause earthquakes, } \\
\text { which may trigger tsunamis. }\end{array}$ & F9020 \\
\hline \multirow{3}{*}{ Attitude + Affection } & $\begin{array}{c}\text { Polar bears are white and cute. They like to eat other } \\
\text { organisms that live in the North Pole. }\end{array}$ & E8012 \\
\hline & $\begin{array}{l}\text { Destruction of the ocean environment threatens the habitat } \\
\text { of sea dolphins. }\end{array}$ & D9010 \\
\hline & $\begin{array}{l}\text { Temperatures around the world are rising. We should } \\
\text { reduce the use of home appliances to conserve energy and } \\
\text { reduce carbon emission. }\end{array}$ & H9011 \\
\hline \multirow{4}{*}{ Knowledge + Affection } & $\begin{array}{l}\text { Seagulls like hovering over beaches and prey upon newborn } \\
\text { sea turtles crawling to the ocean. }\end{array}$ & G8003 \\
\hline & $\begin{array}{l}\text { The abundant fish schools brought by the Kuroshio current } \\
\text { provide fishing boats with an enriched fish supply. }\end{array}$ & F9011 \\
\hline & $\begin{array}{l}\text { While snorkeling in coral reefs, one can spot colorful } \\
\text { clownfish, starfish, and other marine organisms. }\end{array}$ & B9023 \\
\hline & $\begin{array}{l}\text { Snorkeling around Green Island is an ideal recreational } \\
\text { activity during the summer vacation. }\end{array}$ & A7024 \\
\hline \multirow{3}{*}{$\begin{array}{l}\text { Knowledge }+ \text { Attitude }+ \\
\text { Affection }\end{array}$} & $\begin{array}{l}\text { Global warming causes icebergs to melt, which may cause } \\
\text { the sea level to rise and endanger the survival of polar bears. }\end{array}$ & A9016 \\
\hline & $\begin{array}{c}\text { Underwater volcano eruptions may cause tsunamis and } \\
\text { endanger the lives of many people. }\end{array}$ & B9008 \\
\hline & $\begin{array}{c}\text { Currently, the sea level is rising rapidly. We should stop } \\
\text { hunting endangered marine fish. }\end{array}$ & E8011 \\
\hline \multirow{4}{*}{ Misconception } & $\begin{array}{l}\text { Rising temperatures have caused icebergs to melt, which can } \\
\text { cause sea levels to rise and can flood land. }\end{array}$ & E7023 \\
\hline & The sun is the same size as the Earth. & D8011 \\
\hline & Whales cause earthquakes. & G8008 \\
\hline & Flying fish eat seagulls. & F7003 \\
\hline
\end{tabular}

Each letter represents a school. The first number represents a student's grade, and the last three numbers represent a student's serial number. 
Table 4. Analysis of middle school students' sentences containing marine misconceptions.

\begin{tabular}{|c|c|c|}
\hline No. & Misconception Example & Correct Example \\
\hline 1 & Typhoons cause tsunamis. & Intense earthquakes cause tsunamis. \\
\hline 2 & The moon causes ocean tides to rise and fall. & $\begin{array}{c}\text { The Earth and moon cause ocean tides to } \\
\text { rise and fall. }\end{array}$ \\
\hline 3 & $\begin{array}{l}\text { Underwater volcano eruptions in the sea } \\
\text { must exceed sea levels to be cooled down. }\end{array}$ & $\begin{array}{c}\text { Underwater volcano eruptions cool down } \\
\text { by themselves. }\end{array}$ \\
\hline 4 & Rising sea levels may cause tsunamis. & Intense earthquakes may cause tsunamis. \\
\hline 5 & The Earth's rotation causes climate change. & $\begin{array}{l}\text { The Earth's rotation does not cause } \\
\text { climate change. }\end{array}$ \\
\hline 6 & $\begin{array}{l}\text { Currently, Taiwan is referred to as the } \\
\text { Kuroshio current. }\end{array}$ & $\begin{array}{l}\text { The Kuroshio current is the name of an } \\
\text { ocean current. }\end{array}$ \\
\hline 7 & $\begin{array}{l}\text { After earthquakes, all organisms at the } \\
\text { bottom of the sea die. }\end{array}$ & $\begin{array}{l}\text { After earthquakes, some organisms at the } \\
\text { bottom of the sea die. }\end{array}$ \\
\hline 8 & The temperature of icebergs remains $0^{\circ} \mathrm{C}$. & $\begin{array}{l}\text { The temperature of icebergs remains } \\
\text { below } 0{ }^{\circ} \mathrm{C} \text {. }\end{array}$ \\
\hline 9 & Jellyfish electrify flying fish. & Jellyfish sting. \\
\hline 10 & $\begin{array}{l}\text { Underwater volcano eruptions cause } \\
\text { earthquakes and the sea level to rise. }\end{array}$ & $\begin{array}{l}\text { Underwater volcano eruptions cause } \\
\text { earthquakes and release volcanic ash. }\end{array}$ \\
\hline
\end{tabular}

\subsection{Ocean Knowledge Sources of Middle School Students}

The top three sources of the students' ocean knowledge in descending order were museums $(65.4 \%)$, television $(52.8 \%)$, and instruction by teachers (43.5\%). Table 5 presents the students' ocean knowledge sources and frequency. In addition to the official curriculum, these students mainly engaged in educational opportunities of ocean concepts through extracurricular and outdoor diverse learning experiences.

Table 5. Students' ocean knowledge source and examples of middle school students' propositional concept map sentences.

\begin{tabular}{cccc}
\hline Rank & Sources & N & Percentage (\%) \\
\hline 1 & Museum & 449 & 65.4 \\
2 & Television & 363 & 52.8 \\
3 & Instruction by teachers & 299 & 43.5 \\
4 & Educational propaganda & 287 & 41.8 \\
5 & TV Media and cartoons & 274 & 39.9 \\
6 & Movies & 240 & 34.9 \\
7 & Elder relatives & 224 & 32.6 \\
8 & Newspapers and magazines & 117 & 17.0 \\
9 & Other & 11 & 1.6 \\
\hline
\end{tabular}

\subsection{Influence of Background Variables on the Ocean Literacy Performance of Middle School Students}

\subsubsection{Grade}

This study analyzed propositional concept map sentences from the 50 ocean-related concept words according to students' grades and reinterpreted the propositional concept map scale results accordingly (Table 6). In the accuracy dimension, Scheffe post hoc comparison revealed that the accuracy of eighth-graders was significantly greater than that of ninth- and seventh-graders, whereas the accuracy of ninth-graders was greater than that of seventh-graders. In the explanation dimension, Scheffe post hoc comparison indicated that the explanation dimension of the sentences made by the eighth-graders was significantly greater than that of the seventh- and ninth-graders. For the propositional structure 
dimension, Scheffe post hoc comparison revealed that the propositional structure dimension of the ninth-graders was significantly greater than that of the seventh- and eighth-graders, and that of the eight-graders was significantly greater than that of the seventh-graders. From this analysis, the middle school students attained more ocean knowledge as their grades increased.

Table 6. Analysis of middle school students' propositional concept map sentences according to dimension (and student grade).

\begin{tabular}{|c|c|c|c|c|c|c|}
\hline Dimension & Grade & $\mathbf{N}$ & $\mathbf{M}$ & SD & $F$ & Scheffe's Test \\
\hline \multirow{4}{*}{ Accuracy } & 9th & 158 & 34.14 & 12.47 & \multirow{4}{*}{$2.322 *$} & $3>2$ \\
\hline & 8th & 173 & 34.66 & 10.65 & & $2>1$ \\
\hline & 7 th & 165 & 31.93 & 13.70 & & $3>1$ \\
\hline & Total & 496 & 33.59 & 12.34 & & \\
\hline \multirow{4}{*}{ Explanation } & 9th & 158 & 26.36 & 8.82 & \multirow{4}{*}{$34.53 *$} & \\
\hline & 8th & 173 & 26.79 & 7.06 & & $2>1$ \\
\hline & 7 th & 165 & 24.42 & 9.91 & & $3>1$ \\
\hline & Total & 496 & 25.86 & 8.70 & & \\
\hline \multirow{4}{*}{$\begin{array}{l}\text { Proposition } \\
\text { structure }\end{array}$} & 9th & 158 & 41.68 & 14.59 & \multirow{4}{*}{$4.355^{*}$} & $3>2$ \\
\hline & 8th & 173 & 41.19 & 12.09 & & $2>1$ \\
\hline & 7 th & 165 & 37.47 & 15.63 & & $3>1$ \\
\hline & Total & 496 & 40.11 & 14.24 & & \\
\hline \multirow{4}{*}{ Total } & 9th & 158 & 102.20 & 35.44 & \multirow{4}{*}{$3.418 *$} & \multirow{4}{*}{$\begin{array}{l}2>1 \\
3>1\end{array}$} \\
\hline & 8th & 173 & 102.64 & 29.12 & & \\
\hline & 7th & 165 & 93.82 & 38.77 & & \\
\hline & Total & 496 & 99.57 & 34.75 & & \\
\hline
\end{tabular}

\subsubsection{Gender}

This study analyzed the propositional concept map sentences based on 50 ocean-related concept terms according to the students' gender and reinterpreted the propositional concept map scale results accordingly (Table 7). This analysis indicated that the average ocean literacy score of female students was higher than that of male students.

Table 7. Analysis of middle school students' propositional concept map sentences according to dimension (and student gender).

\begin{tabular}{cccccc}
\hline Dimension & Gender & $\mathbf{N}$ & $\mathbf{M}$ & $\mathbf{S D}$ & $\mathbf{t}$ \\
\hline \multirow{2}{*}{ Accuracy } & Males & 240 & 32.62 & 12.4 & \multirow{2}{*}{1.698} \\
& Females & 256 & 34.50 & 12.24 & \\
\hline \multirow{2}{*}{ Explanation } & Males & 240 & 25.53 & 8.91 & -0.832 \\
& Females & 256 & 26.18 & 8.50 & \\
\hline \multirow{2}{*}{ Proposition } & Males & 240 & 39.40 & 14.50 & \multirow{2}{*}{ structure } \\
\multirow{2}{*}{ Total } & Females & 256 & 40.79 & 13.99 & \\
& Males & 240 & 97.55 & 35.28 & \multirow{2}{*}{-1.26} \\
\hline
\end{tabular}

\subsubsection{School Location}

This study classified the location of the sampled students' schools as follows. If a school was situated on a plain, it was classified as a coastal school; if the school was situated in the hills, it was classified as a noncoastal school. Western Taiwan has a long coastline; as rivers carried sediment into the sea, it accumulated near river mouths to form plains. Eastern Taiwan has a rocky coastline, and because of the neighboring mountains, the coastline is more uneven and mostly mountainous 
or hilly. On the basis of these criteria, the propositional concept map scale results were reinterpreted (Table 8). According to these results, the overall mean ocean literacy score of students in coastal schools was significantly higher than that of students in noncoastal schools.

Table 8. Analysis of middle school students' propositional concept map sentences according to dimension (and school location).

\begin{tabular}{cccccc}
\hline Dimension & Variable & $\mathbf{N}$ & $\mathbf{M}$ & $\mathbf{S D}$ & $\mathbf{T}$ \\
\hline \multirow{2}{*}{ Accuracy } & Coastal school & 359 & 35.67 & 9.63 & \multirow{2}{*}{$5.07^{* * *}$} \\
& Inland school & 137 & 28.12 & 16.39 & \multirow{2}{*}{$5.08^{* * *}$} \\
\hline \multirow{2}{*}{ Explanation } & Coastal school & 359 & 27.39 & 6.33 & \multirow{2}{*}{$5.42^{* * *}$} \\
& Inland school & 137 & 21.86 & 12.15 & \multirow{2}{*}{ *.26** } \\
\hline \multirow{2}{*}{ Proposition } & Coastal school & 359 & 42.76 & 10.40 & \\
structure & Inland school & 137 & 33.18 & 19.67 & \\
\hline \multirow{2}{*}{ Total } & Coastal school & 359 & 105.83 & 25.62 & \\
& Inland school & 137 & 83.16 & 47.89 & \\
\hline & & & & &
\end{tabular}

\subsubsection{Families Working in Marine Industries}

This study analyzed the propositional concept map scale results based on whether the students' families worked in marine industries (Table 9). This analysis indicated that the ocean literacy scores of students whose families worked and did not work in marine industries did not exhibit significant differences.

Table 9. Analysis of middle school students' propositional concept map sentences according to dimension (and whether a student's family worked in marine industries).

\begin{tabular}{cccccc}
\hline Dimension & Variable & $\mathbf{N}$ & $\mathbf{M}$ & $\mathbf{S D}$ & $\mathbf{t}$ \\
\hline \multirow{2}{*}{ Accuracy } & Marine-related industries & 71 & 34.11 & 12.34 & \multirow{2}{*}{0.388} \\
& Non-marine-related industries & 425 & 33.49 & 12.35 & \\
\hline \multirow{2}{*}{ Explanation } & Marine-related industries & 71 & 26.67 & 8.67 & \multirow{2}{*}{0.844} \\
& Non-marine-related industries & 425 & 25.73 & 8.70 & \\
\hline \multirow{2}{*}{$\begin{array}{c}\text { Proposition } \\
\text { structure }\end{array}$} & Marine-related industries & 71 & 41.05 & 13.98 & \multirow{2}{*}{0.602} \\
\hline \multirow{2}{*}{ Total } & Non-marine-related industries & 425 & 39.95 & 14.29 & \multirow{2}{*}{0.596} \\
& Marine-related industries & 71 & 101.85 & 34.39 & \\
\hline
\end{tabular}

\section{Discussion}

\subsection{Middle School Students' Usage and Misconceptions of Ocean Concept Words}

The middle school students' usage and misconceptions of ocean concept words indicated that official school courses, media information, and daily engagement with ocean knowledge greatly influenced students' ocean knowledge. However, this result differs among students at different educational levels. For example, US students exhibit low levels of knowledge and usage of terms regarding ocean science and aquatic life [23]. Feller [53] listed 110 misconceptions about tides, geography, climate, organic beings, mammals, seafood ingredients, and environmental pollution themes that college students may have and provided teachers with key concepts that should be clarified in classrooms. Taiwanese high school students' ocean misconceptions primarily comprise themes on ocean climate and organic resources. In particular, these misconceptions involved the terms "Kuroshio current," "Oyashio current," and "bioenergy" [16,17]. Sources of misconceptions included observations in daily life and intuitive experience, incorrect knowledge from textbooks, 
improper teaching processes, peer influences, insufficient course knowledge, misunderstanding during learning, and specific environments $[60,61]$. In courses, misconceptions are key factors that impede student learning. To help students develop correct concepts, the cause of misconceptions must first be understood to quickly correct students' thinking.

\subsection{Middle School Students' Ocean Knowledge Sources}

Students' sources of ocean knowledge indicated that mass communication channels are crucial for them to acquire ocean knowledge. International surveys on the sources of ocean literacy have revealed that popular science sources (e.g., reading magazines and books) and media applications (e.g., television media and online education) are key factors in enhancing students' ocean knowledge and literacy $[18,62]$.

\subsection{Influence of Background Variables on Middle School Students' Ocean Literacy Performance}

Post hoc comparisons of statistical results (Table 8) revealed that eighth-grade students exhibited significantly higher performance in the accuracy, explanation, and proposition structure dimensions than did ninth- and seventh-grade students. Research on the program for the infusion of fundamental concepts of marine education in primary and secondary school curriculum guidelines in Taiwan has indicated that middle school students achieved only $80 \%$ of ocean literacy competency indicators [14]. Furthermore, the mean scores of Taiwanese middle school students in the accuracy, explanation, and proposition structure dimensions were low. This result was consistent with those of other studies, which posited that students of different grades have different levels of ocean literacy and that ocean literacy increases with grade. This suggests that ocean literacy and the course content received by students gradually increased in breadth and width as they progressed to the next grade [19]. In particular, the ocean literacy scores of students of different grades were significantly different in the explanation and proposition structure dimensions, which indicated that the students' ocean literacy was related to their sentence-making and conjunction usage skills in the language arts field. However, the ocean literacy scores of students in different grades were not significantly different in the accuracy dimension, which indicated that the students generally had insufficient knowledge in vocabulary usage and ocean knowledge and concepts.

A comparison between the assessment results of students of both sexes revealed that the two sexes did not have significantly different performance levels. However, this result differed from that of a US study. In recent years, improvements have been made regarding gender differences in course learning. However, ocean literacy concepts primarily consist of scientific knowledge. Studies have indicated that the average ocean literacy scores of male students are higher than those of female students. Research investigations have revealed that male students are more likely to list examples of channels for acquiring ocean knowledge and concepts, such as through watching television and reading textbooks. However, few female students mentioned channels of acquiring ocean-related concepts $[19,52,53]$. In addition, the middle school students' test results on the ocean literacy scale revealed that the amounts of knowledge and ocean concepts acquired by the students did not differ according to gender. However, ocean literacy performance between genders was influenced by the difficulty of the questions asked [20]. Therefore, the source of ocean concepts for students of both genders and how they express ocean literacy concepts merits further discussion.

The assessment results of the ocean literacy concepts of students who attended schools in a given location revealed that the total mean score of students who attended coastal and noncoastal schools was 105.83 and 83.16, respectively. The total mean score of students from coastal schools was significantly higher than that of students from noncoastal schools. This result indicated that coastal schools could more easily integrate knowledge and concepts pertaining to the local ocean when teaching marine education courses. Coastal schools generally adopt marine education to teach courses and integrate ocean topics into courses for each discipline. In Taiwan, different districts of the country allow for the implementation of different curricula and/or school textbooks. This enables students to apply what 
they learn in their everyday lives. Therefore, the ocean literacy scores of students from coastal schools were significantly higher than those of students from noncoastal schools. In addition, coastal schools have convenient access to coastal teaching sites. Teachers at coastal schools can employ neighboring communities and their lifestyles as course material and design teaching activities to provide students with a greater degree of interaction with the ocean during the learning process. This result was similar to that of a comprehensive investigation on the implementation of marine education in middle and elementary schools in Japan, which indicated that coastal schools adopted experiential, environmental, and local ocean-related educational activities to enhance students' ocean knowledge and concepts on marine environments, aquatic resources, and shipping transportation. Therefore, students from coastal schools had significantly higher degrees of ocean literacy than did noncoastal schools [44]. The results of a study in which Taiwanese scholars constructed an ocean literacy scale for high school students revealed that school location is a key factor $[13,18]$. However, this result differed from that of a US survey on Virginian students [23]. Therefore, school location could be a key influence on students' ocean literacy.

Finally, whether a student's family worked or did not work in marine industries (e.g., the fishery, maritime, aquaculture, and fish processing industries) did not cause significant differences in terms of ocean literacy. The total mean score for the three dimensions of students whose family members worked in and did not work in marine industries was 101.85 and 99.19, respectively. This indicated that students whose family members worked in marine industries had greater understanding of ocean concepts than did students whose family members did not work in such industries. Other relevant Taiwanese studies have indicated that parents' education level positively influences the cultivation of students' ocean attitude and literacy. In particular, parents with high education levels were indirectly related to the cultivation of ocean attitudes and literacy among female students [63].

\section{Conclusions}

The accuracy, explanation, and proposition structure dimensions were combined to assess the propositional concept map sentences. The full score of each dimension was set as 50 points, under which students' mean scores in the accuracy, explanation, and proposition structure dimensions were $33.28,30.86$, and 31.60 , respectively. In addition, the full total score of the scale was set as 150 , under which the students' mean total score was 95.74. The mean scores of each dimension and the total scale indicated that middle school students' ocean literacy was at a basic level and had room for improvement. Education can integrate ocean knowledge and concepts into courses to design satisfactory marine educational activities and teaching strategies to enhance students' overall ocean literacy.

Assessment and analysis of the propositional concept map sentences revealed that students of different grades exhibited differences in ocean literacy. Students in higher grades that had ocean-related courses had a greater breadth and depth of knowledge. Furthermore, a school's location determined its course development process. Most schools developed courses according to the school's features, environment, and conditions by integrating neighboring environments, parents in local communities, teacher expertise, and student demands into the course design. Because of their proximity to and engagement with the ocean in their living spaces, instructors in coastal schools can design and integrate ocean-oriented literacy courses. Finally, ocean concepts primarily contain scientific information. Studies have indicated that the science and literacy scores of men were greater than those of women. This result differed from that of the current study. Therefore, future studies are suggested to explore this phenomenon.

The investigation of ocean knowledge sources revealed that students primarily acquired ocean knowledge through visiting museums and watching television programs about the ocean. Although community education centers (e.g., marine education resource center) are a reliable channel to impart knowledge, community centers employ informal courses to teach students ocean knowledge. For example, there are 22 counties in Taiwan, each of which has its own Marine Education Resource Center. Each center conducts a marine education curriculum and promotion for elementary and junior high 
school students in accordance with the annual theme of World Ocean Day. The results indicated that more participants engaged with ocean knowledge through the media than did those who engaged in ocean knowledge through formal education. However, whether the ocean knowledge transmitted by television programs is accurate remains to be studied. Educators should adjust and enhance the amount of ocean-related content and courses taught in formal education. After propositional concept map sentences were used to assess students' ocean concepts, the results were compiled, revealing that most students had misconceptions regarding the concept terms "sea level rising," "Kuroshio current," and "tsunami." This indicated that although the students were familiar with these terms, they were not guaranteed to have correct concepts of them. During class, teachers should pay attention to whether students hold misconceptions toward familiar and everyday concept words. In addition, teachers can provide detailed explanations to facilitate students' understanding to enable them to accumulate learning experiences and develop expertise in ocean concepts and enhance their ocean literacy.

It is proposed that in the future research, ocean literacy can be assessed using longitudinal studies with students of different grades. In addition, background variables can be analyzed in order to understand the ocean literacy performance of students.

Author Contributions: L.-T.T., Y.-L.L. and C.-C.C. conceived and designed the study and drafted the article; L.-T.T. and Y.-L.L. participated in the design of the study and interpreted data; L.-Y.W. and C.-C.C. collected and assembled data. All authors have read and agreed to the published version of the manuscript.

Funding: This research was funded by Ministry of Science Technology, Taiwan, grant number MOST-108-2511-H-019-001-MY3 and MOST-107-2515-H-019-002-MY2.

Acknowledgments: The authors thank the participants.

Conflicts of Interest: The authors declare no conflict of interest.

\section{References}

1. United Nations Division for Sustainable Development. Agenda 21: Programme of Action for Sustainable Development. 1992. Available online: https://sustainabledevelopment.un.org/outcomedocuments/agenda21 (accessed on 18 August 2020).

2. United Nations Educational, Scientific and Cultural Organization. United Nations Decade of Education for Sustainable Development, 2005-2014: Draft International. 2005. Available online: https://en.unesco.org/ themes/education-sustainable-development/what-is-esd/un-decade-of-esd (accessed on 18 August 2020).

3. United Nations. Convention on the Law of the Sea; United Nations: New York, NY, USA, 1982.

4. Markos, A.; Boubonari, T.; Mogias, A.; Kevrekidis, T. Measuring ocean literacy in pre-service teachers: Psychometric properties of the Greek version of the survey of ocean literacy and experience (SOLE). Environ. Educ. Res. 2017, 23, 231-251. [CrossRef]

5. Fauville, G.; Strang, C.; Cannady, M.A.; Chen, Y.F. Development of the international ocean literacy survey: Measuring knowledge across the world. Environ. Educ. Res. 2019, 25, 238-263. [CrossRef]

6. Chang, T.C. Analyzing the Objectives and Implementation of Marine Education in Elementary and Middle Schools from Environmental Education Perspective. In Proceedings of the Ocean Love of International Ocean Year Symposium, Keelung, Taiwan, 17 October 1998; pp. 62-70.

7. Executive Yuan (Taiwan). Whitepaper of Marine Policy; Executive Yuan: Taipei, Taiwan, 2006.

8. Ministry of Education (Taiwan). A Whitepaper on the Marine Education Policy; MOE: Taipei, Taiwan, 2007.

9. Ministry of Education (Taiwan). Grade 1-9 Curriculum Guidelines-Important Issues on Marine Education; MOE: Taipei, Taiwan, 2008.

10. Ministry of Education (Taiwan). A Whitepaper on the Marine Education Policy, 2nd ed.; MOE: Taipei, Taiwan, 2017.

11. National Academy Education Research (Taiwan). Curriculum Guidelines of 12-Year Basic Education Guidelines of Issue-Based Curriculum Integration in Elementary School and General Senior High School; NAER: New Taipei, Taiwan, 2019; pp. 52-57.

12. Chang, C.C. A Study on the influential factors of marine science knowledge and capability indicators for junior high school students. Educ. J. 2015, 43, 173-196.

13. Ministry of Education (Taiwan). Program for Infusion Fundamental Conception of Marine Education in Primary and Secondary School Curriculum Guideline; Final Report; MOE: Taipei, Taiwan, 2008. 
14. Sheu, T.J. Construction of competence indicators and weight system of marine education for elementary school teachers. J. Res. Educ. Sci. 2011, 56, 61-90.

15. Chung, K.N.; Lee, Z.Z.; Fang, L.S. The directions of marine education. In Sustainable for Marine Development; Chiu, W.Y., Ed.; Hu's Bookstore: Taipei, Taiwan, 2003; Volume 4, pp. 205-223.

16. Lwo, L.S.; Chang, C.C.; Tung, Y.P.; Yang, W.C. Marine science literacy and misconceptions among senior high school students. J. Res. Educ. Sci. 2013, 58, 51-83.

17. Chang, C.C.; Yang, W.C.; Lwo, L.S. Evaluating vocational high school students' marine science literacy and their misconceptions. Sci. Educ. Mon. 2014, 371, 2-17.

18. Tsai, L.T. Multilevel effects of student and school factors on senior high school students' ocean literacy. Sustainability 2019, 11, 5810. [CrossRef]

19. Chang, C.C. Development of ocean literacy inventory for 16-to 18-year-old students. SAGE Open 2019, 9, 1-15. [CrossRef]

20. Tsai, L.T.; Chang, C.C. Measuring ocean literacy of high school students: Psychometric properties of a Chinese version of the ocean literacy scale. Environ. Educ. Res. 2019, 25, 264-279. [CrossRef]

21. Tung, Y.P. Implementing Concept Mapping to Evaluate Senior High School Students' Marine Science Misconceptions-A Case Study of Keelung. Master's Thesis, National Taiwan Ocean University, Keelung, Taiwan, 2012.

22. United Nations Educational, Scientific and Cultural Organization. Year 2000 Challenges for Marine Science Training and Education Worldwide; UNESCO: Paris, France, 1989.

23. Fortner, R.W.; Mayer, V.J. Ohio students' knowledge and attitudes about the oceans and great lakes. Ohio J. Sci. 1983, 83, 218-224.

24. Brody, M.J.; Koch, H. An assessment of 4th-, 8th-, and 11th-Grade students' knowledge related to marine science and natural resource issues. J. Environ. Educ. 1990, 21, 16-26. [CrossRef]

25. Steel, B.S.; Smith, C.; Opsommer, L.; Curiel, S.; Warner-Steel, R. Public ocean literacy in the United States. Ocean. Coast. Manag. 2005, 48, 97-114. [CrossRef]

26. The Ocean Project: America, the Ocean, and Climate Change: Key Findings. Available online: https: //theoceanproject.org/reports/\#2009 (accessed on 1 June 2020).

27. Ocean Literacy: The Essential Principles of Ocean Science K-12. Available online: http://oceanliteracy.wp2. coexploration.org (accessed on 1 June 2020).

28. National Marine Educators Association. Ocean Literacy Scope and Sequence for Grades K-12; The Ocean Literacy Campaign Featuring the Ocean Literacy Scope E Sequence for Grades K-12; NMEA: Mississippi, MS, USA, 2010; Available online: https://www.marine-ed.org/ocean-literacy/scope-and-sequence (accessed on 1 June 2020).

29. Schroedinger, S.; Cava, F.; Strang, C.; Tuddenham, P. Ocean Literacy through Science Standards. 2005. Available online: https:/coexploration.org/oceanliteracy/documents/workshopreport.pdf (accessed on 18 August 2020).

30. Khataybeh, A.; Subbarini, M.; Shurman, S. Education for sustainable development, an international perspective. Procedia Soc. Behav. Sci. 2010, 5, 599-603. [CrossRef]

31. Goodale, T.A. Factors That Influence Curricular Adoption in a Sustainability Focused Marine Science Professional Development for In-Service Teachers. J. Educ. Sustain. Dev. 2020. [CrossRef]

32. Greely, T. Ocean Literacy and Reasoning about Ocean Issues: The Influence of Content, Experience, and Morality. Ph.D. Thesis, University of South Florida, Tampa, FL, USA, 2008.

33. Lambert, J. Students' conceptual understandings of science after participating in a high school marine science course. J. Geosci. Educ. 2005, 53, 531-539. [CrossRef]

34. Ausubel, D.A. Educational Psychology. A Cognitive View; Holt, Rinehart \& Winston: New York, NY, USA, 1968.

35. Wandersee, J.H. Concept mapping and the cartography of cognition. J. Res. Sci. Teach. 1990, 27, $923-936$. [CrossRef]

36. Novak, J.; Gowin, D.B. Learning How to Learn; Cambridge University Press: Cambridge, UK, 1984.

37. Heinze-Fry, J.A.; Crovello, T.J.; Novak, J.D. Integration of ausubelian learning theory and educational computing. Am. Biol. Teach. 1984, 46, 152-156.

38. Piaget, J. Science of Educational and the Psychology of the Child, 5th ed.; Viking Press: New York, NY, USA, 1972.

39. Osborne, R.J.; Wittrock, M.C. Learning science: A generative process. Stud. Sci. Educ. 1983, 67, 489-508. [CrossRef]

40. Mason, C.L. Concept mapping: A tool to develop relative science education. Stud. Sci. Educ. 1992, 76, 51-63. 
41. Yu, M.N. Meaning Learning: Introduce Concept Map; Shinning Culture Publishing: Taipei, Taiwan, 1997.

42. Harrison, A.G.; Grayson, D.J.; Treagust, D.F. Investigating a Grade 11 Student's Evolving Conceptions of Heat and Temperature. J. Res. Sci. Teach. 1999, 36, 55-87. [CrossRef]

43. Tyson, L.M.; Venville, G.J.; Harrison, A.G.; Treagust, D.F. A multidimensional framework for interpreting conceptual change events in the classroom. Stud. Sci. Educ. 1997, 81, 387-404. [CrossRef]

44. Ocean Policy Research Foundation. Grand Design for Ocean Education in the 21st Century: Ocean Education Curriculum and Unit Plans; Nippon Foundation: Tokyo, Japan, 2011.

45. Goodwin, C. Seeing in depth. Soc. Stud. Sci. 1995, 25, 237-274. [CrossRef]

46. Mukerji, C. A Fragile Power: Scientists and the State; Princeton University Press: Princeton, NJ, USA, 1989.

47. Libarkin, J.C.; Anderson, S.W.; Dahl, J.; Beilfuss, M.; Boone, W. Qualitative analysis of college students' ideas about the earth: Interviews and open-ended questionnaires. J. Geosci. Educ. 2005, 53, 17-26. [CrossRef]

48. Kean, W.F.; Posnanski, T.J.; Wisniewski, J.J.; Lundberg, T.C. Urban earth science in Milwaukee Wisconsin. J. Geosci. Educ. 2004, 52, 433-437. [CrossRef]

49. Semken, S. Sense of place and place-based introductory geoscience teaching for American Indian and Alaska native undergraduates. J. Geosci. Educ. 2005, 53, 149-157. [CrossRef]

50. Mogias, A.; Boubonari, T.; Realdon, G.; Previati, M.; Mokos, M.; Koulouri, P.; Cheimonopoulou, M.T. Evaluating Ocean Literacy of Elementary School Students: Preliminary Results of a Cross-Cultural Study in the Mediterranean Region. Front. Mar. Sci. 2019, 6, 1-14. [CrossRef]

51. American Association for the Advancement of Science. AAAS Survey Report; AAAS: Washington, DC, USA, 2004.

52. Greely, T.; Lodge, A. Measuring Ocean Literacy: What Teens Understand about the Ocean Using the Survey of Ocean Literacy and Engagement (SOLE). In Proceedings of the 2009 Fall Meeting of the American Geophysical Union, San Francisco, CA, USA, 14-18 December 2009.

53. Feller, R.J. 110 Misconceptions about the ocean. Oceanography 2007, 20, 170-173. [CrossRef]

54. Common Misconceptions about Oceans. Available online: http://beyondpenguins.ehe.osu.edu/issue/polaroceans/common-misconceptions-about-oceans (accessed on 1 June 2020).

55. Wandersee, J.H.; Mintzes, J.J.; Novak, J.D. Research on alternative conceptions in science. In Handbook of Research on Science Teaching and Learning; Gabel, D.L., Ed.; Simon \& Schuster and Prentice Hall International: New York, NY, USA, 1994; pp. 177-210.

56. Wallace, J.D.; Mintzes, J.J. The concept map as a research tool: Exploring conceptual change in biology. J. Res. Sci. Teach. 1990, 27, 1033-1052. [CrossRef]

57. Goldsmith, T.E.; Johnson, P.J.; Acton, W.H. Assessing structural knowledge. J. Educ. Psychol. 1991, 83, 88-96. [CrossRef]

58. Stoddart, T.; Abrams, R.; Gasper, E.; Canaday, D. Concept maps as assessment in science inquiry learning report of methodology. Int. J. Sci. Educ. 2000, 22, 1221-1246. [CrossRef]

59. Forehand, M. Bloom's taxonomy. In Emerging Perspectives on Learning, Teaching, and Technology; Orey, M., Ed.; Createspace Independent Pub.: California, CA, USA, 2010; pp. 41-47.

60. Novick, S.; Nussbaum, J. Pupil's understanding of the particulate nature of matter: A cross-age study. Sci. Educ. 1981, 65, 187-196. [CrossRef]

61. Ponser, G.J.; Strike, K.A.; Hewson, P.W.; Gertzog, W.A. Accommodation of a scientific conception: Toward a theory of conceptual change. Sci. Educ. 1982, 66, 211-227.

62. Cudaback, C. What do college students know about the ocean? Eos. Trans. AGU 2006, 87, 418-421. [CrossRef]

63. Tsai, L.T.; Lin, Y.L.; Chang, C.C. An assessment of factors related to ocean literacy based on gender-invariance measurement. Int. J. Environ. Res. Publ. Health 2019, 16, 3672. [CrossRef]

(C) 2020 by the authors. Licensee MDPI, Basel, Switzerland. This article is an open access article distributed under the terms and conditions of the Creative Commons Attribution (CC BY) license (http://creativecommons.org/licenses/by/4.0/). 